INSIGHTS INTO REGIONAL DEVELOPMENT

ISSN 2669-0195 (online) http://jssidoi.org/IRD/

2021 Volume 3 Number 2 (June)

http://doi.org/10.9770/IRD.2021.3.2(1)

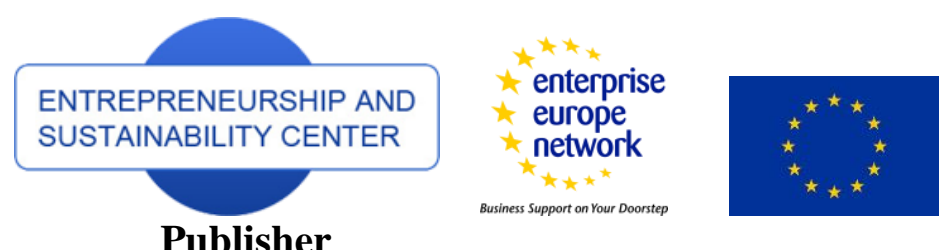

http://jssidoi.org/esc/home

\title{
INFRASTRUCTURE AND SECTORAL FDI INFLOWS IN CHINA: AN EMPIRICAL ANALYSIS
}

\author{
Faisal Mehmood ${ }^{1}$, Muhammad Atique ${ }^{2}$, Wang Bing ${ }^{3}$, Hameed Khan ${ }^{4 *}$, Henna ${ }^{5}$ \\ ${ }^{1,2,3}$ College of Public Administration, Huazhong University of Science \& Technology, Wuhan, China \\ ${ }^{4}$ Department of Economics, Kohat University of Science \& Technology, Kohat, Pakistan \\ ${ }^{5}$ Institute of Business Studies, Kohat University of Science \& Technology, Kohat, Pakistan \\ E-mails: ${ }^{1}$ fmehmood_kmu@yahoo.com; ${ }^{2}$ muhammad.atique1@yahoo.com; ${ }^{3}$ wbyf@mail.hust.edu.cn; \\ 4*hameed.qec@gmail.com (Corresponding author); hennagulawat@gmail.com
}

Received 20 September 2020; accepted 25 March 2021; published 30 June 2021

\begin{abstract}
In this paper, for the first time, we investigate the relationship between infrastructure and sectoral distribution of FDI inflow in China. We use the Estimating Autoregressive Distributed Lag (ARDL) bound testing and Vector Error Correction Model (VECM) procedures of estimation. To unmask the shortcomings in the previous literature, we use a composite index of infrastructure with more than 30 indicators. The results show that there is a long-run relationship between sectoral FDI and infrastructure. A bidirectional causal relationship is confirmed by using VECM. However, we find unidirectional causality between the primary sector's FDI and infrastructure, and it is running from infrastructure to primary sector FDI. The inclusion of control variables, e.g., institutional quality, trade openness, and domestic investment, is robust in our analysis. The positive role of infrastructure in the sectoral distribution of FDI inflows is of utmost importance for policymakers and Chinese-government. Several policy implications are given in our study.
\end{abstract}

Keywords: Infrastructure; foreign direct investment; Estimating Autoregressive Distributed Lag (ARDL)

Reference to this paper should be made as follows: Mehmmod, F., Bing, W., Atique, M., Khan, H. 2021. Infrastructure and Sectoral FDI in China: An Empirical Analysis. Insights into the regional development, 3(2), 160-175. http://doi.org/10.9770/IRD.2021.3.2(1)

JEL Classifications: F21; C22; O17

\section{Introduction}

The recent global financial crisis 2008 encourages the Chinese government to invest in infrastructure by 4 trillion Chinese Yuan (equivalent to 600 billion US dollars) as a fiscal stimulus package in its western provinces in 2008 (Ouyang \& Peng, 2015). 1 trillion Chinese Yuan was further proposed to invest in infrastructure since the Chinese economy started to slow down in 2015 (Financial Times, August 5, 2015). Meanwhile, the miraculous surge in foreign direct investment in China is one of the key phenomena in the modern globalized world (Khan \& Khan, 2019; Khan, Shaheen, et al., 2020). China became the second-largest destination all over the world. Therefore, a 


\section{INSIGHTS INTO REGIONAL DEVELOPMENT}

ISSN 2669-0195 (online) http://jssidoi.org/jesi/

2021 Volume 3 Number 2 (June)

http://doi.org/10.9770/IRD.2021.3.2(1)

question of whether the infrastructure explains the FDI inflow naturally arises? Similarly, another question arises, 'whether the sectoral distribution of FDI is complementary in infrastructure development in China'?

During 2017, the tertiary sector (services) portion in total FDI is $66 \%$, secondary sector (manufacturing) portion is $32 \%$ and the primary sector (agriculture, fishing \& mining) counted for only $2 \%$. China ranked the third largest FDI recipient country after the UK and USA in the year 2015. Similarly, by the year 2012, the largest share of foreign investment in China is from Hong Kong (70\%), while in the shares of FDI in China by North America, Europe, and Latin America are 2\%, 3\% and 9\% respectively.

On the outset of reforms; the first thing that happened is the Deng Xiaoping came to power and normalized relations with the USA. Deng took a trip to the USA and immediately announced the joint venture law designed to encourage foreign technologies to come to China. He mainly aims to bring technology to help to Chinese economy advance. When Deng visited the USA, very specifically went to Hi-tech cities like including Houston to see signal what China wants to collaborate with high technology firms. The joint venture law carried many specific provisions designed to entice foreign firms to invest in China. The first was that it provides very generous tax rate.

Previous literature focuses on the impact of infrastructure on aggregate FDI at the national level or cross-country analysis. The previous studies documented a single aspect of infrastructure like transport, ICT (internet \& telecommunications) railways, etc. Keeping in view the expediency of FDI inflows and unmask the information for policy implications and in-depth knowledge, we, for the first time, contribute the literature by investigating the relationship between infrastructure and sectoral distribution of FDI. The earlier literature has never documented the role of institutional quality in FDI-infrastructure relationship in developing countries like China. We contribute the literature by using ARDL approach. Moreover, we contribute the earlier literature by adding an important variable, i.e., institutional quality.

Moreover, our contribution is the analysis of FDI and infrastructure relationship in a broader set of infrastructure indicators, which compose of transport, energy, communication, and finance. Therefore, foreign enterprises choose China as their destination for business by considering various dimensions of infrastructure. Similarly, the sectoral distribution of FDI affects the infrastructure.

The study is divided into sections as the following. Section 1 shows the introduction. The second section describes the stylized facts of infrastructure and FDI in China, followed by the theoretical framework of FDI and infrastructure relationship. Section IV shows the data and methodology. Section V reports empirical results. In section VI, we show the concluding remarks of the study.

\section{Overview of China-infrastructure}

China has emerged as the world's fastest-growing economy. This process started in 1978, the economic reform and opening up its doors to the rest of the world. Today, China is no longer an isolated country and attracted the attention of the international community as a global player on the World stage. We highlight three crucial sectors of infrastructure, i.e., transport, energy, and ICT (internet and telecommunications) in China.

China is endowed with vast land. Around 1.5 billion people are residing in China. To meet the growing demand for infrastructure, its government brought many reforms. In this study, we use physical infrastructure (e.g., transport, energy, ICT, and finance). 
INSIGHTS INTO REGIONAL DEVELOPMENT

ISSN 2669-0195 (online) http://jssidoi.org/jesi/

2021 Volume 3 Number 2 (June)

http://doi.org/10.9770/IRD.2021.3.2(1)

\subsection{Transport infrastructure}

China is the most populous country in the world. Since China's reforms in its economy in 1982, China favored economic growth with an emphasis to have considerable investments in infrastructure. Mainland China has different constraints since it is much vast, and the population density is much lower at 389 people per square mile. Beijing itself is much denser on average. However, at 3200 people per square mile, it still is about one-fourth of Hong Kong population density. This means investing in a more expensive solution to reducing traffic is less utilized. They rely more heavily on road traffic which in China carries virtually half of all passengers' traffic. This causes the infrastructure to favor small roads, high buildings, and more expensive solutions like subways. Beijing is a major cultural and political center; therefore, its priorities are not centered on the same ones as other cities. Beijing has preserved many of the roads and streets from its long past. While small roads are kept, new roads are made to be spectacular in epic and scale.

China has focused heavily on infrastructure construction since starting his reform and opening-up process in 1978. It invested in developing modern highways and high-speed railways. Key cities are being connected, which helps the economy to expand rapidly. With a vast land, it was difficult for Beijing to connect with other parts of the country. The launch of HSR, in 2008, connected two major cities, i.e., Beijing and Tianjin, and it carries around 80,000 thousand passengers per day. Jiao et al. (2014) argue that China had the largest HSR (high-speed rail) network $(9760 \mathrm{~km})$, accounting for $46 \%$ of the world totals by 2013 . China is increasingly spending on transport infrastructure to boost the economy. The high-speed intercity railways have been playing a pivotal role in boosting the local economy. HSR effectively merges cities providing favorable conditions for the exchange of commerce and trade. The high-speed railway is becoming more important to national economic and social development. Since its launch in 2008, the overall passenger transport volume of China's railways has increased by $10 \%$ annually reaching 2.8 billion passengers in 2016 .

Despite the popularity of the high-speed railways, road users have not been forgotten. China has modernized and extended its road network adding new expressways to crucial routes. China now has the world's biggest road network. Most of China's expressways are built with government funding bank loans and other sources of financing, including toll roads. The expressway toll policy has boarded the financing channels of expressway construction. China has a diversified investment and financing model that includes national investment, local fundraising, social financing, and foreign capital. China's development of modern expressways and world-class high-speed railways has transformed the country. It has grown the economy in the process and changed the way people travel across China. Keeping in view the transportation infrastructure, we give the details of its aspects in Table 1. The length of highways and railway increased from 890,200 km and 51,700 km in 1978 to 4,773,500 km and $127,000 \mathrm{~km}$ in 2017 , respectively. Rail is an essential mean of transportation in China. The substantial Chinese investment on BRI (Belt \& Road Initiative) in railway sector would enable it to connect with Europe and Central Asian markets. Since 2011, the considerable investments in the railway sector and the launch of China Railway Express service also helped China to connect its cities with 15 European countries

Table 1. The total length of transport in China $(10,000 \mathrm{~km})$.

\begin{tabular}{|l|l|l|l|l|l|l|}
\hline Year & Expressway & Highway & Railway & Inland waterway & Pipeline & Civilian flight routes \\
\hline 1978 & 0 & 89.02 & 5.17 & 13.6 & 0.83 & 14.89 \\
1990 & 0.05 & 102.83 & 5.78 & 10.92 & 1.59 & 50.68 \\
2000 & 1.63 & 140.27 & 6.87 & 11.93 & 2.47 & 150.29 \\
2010 & 7.41 & 400.82 & 9.12 & 12.42 & 7.85 & 276.51 \\
2017 & 13.64 & 477.35 & 12.70 & 12.70 & 11.93 & 748.30 \\
\hline $2017 / 1978$ & 272.80 & 5.36 & 2.46 & 0.93 & 14.37 & 50.26 \\
\hline
\end{tabular}




\subsection{Energy infrastructure}

Excessive energy demands accompany China's rapid economic growth. China has been given the blessing and the curse of being one of the largest energy consumers and was rapidly growing energy consumers over the last decade. That comes with significant benefits and some significant drawbacks. One of which is trying to procure enough energy to maintain rapid economic growth. China imports probably 60 percent of the oil that it consumes. It is the World largest oil importer. Similarly, coal is China's largest source of energy. $70 \%$ of the nation is coalpowered.

China has been doing a lot to make sure that its energy consumption across a range of fuels is more secure, affordable, and reliable. China is increasing its production domestically to the extent possible. It has some pretty impressive unconventional shale gas resources and moving into it's own offshore to produce more oil and gas. China has also been looking to diversify its imports, especially on the oil and natural gas side from the variety of different sources. Chinese national oil companies have spent around 9 billion dollars over a short period. The companies are trying to access and develop oil resources around the World, and contribute approximately 2 million barrels a day to their overall consumption. China has been able to grow its solar capacity and wind capacity. Now China is one of the largest markets for renewable energy technologies and services around the world. China is connecting all of that renewable energy power generation to the sources of consumption. Companies like State Grid Corporation of China and others are creating these lengthy sorts of transmission lines and plans to connect some of these resources from the big sort of renewable energy production centres to some of the consumption centres in the country. Table 2 shows that China has decreased coal consumption from $76.2 \%$ in 1990 to $60.4 \%$ in 2017, while its coal production decreased from $74.2 \%$ in 1990 to $69.6 \%$ in 2017. The clean energy consumption has been increased from 5.1\% to $13.8 \%$ during 1990 to 2017, and its production increased from $4.8 \%$ to $17.4 \%$ from 1990 to 2017. The figures highlighted the importance of renewables for China.

Table 2. Consumption and production of energy and its composition (in percent)

\begin{tabular}{|c|cccc|c|c|c|c|}
\hline \multirow{2}{*}{ Year } & \multicolumn{4}{|c|}{ Consumption } & \multicolumn{4}{c|}{ Production } \\
\cline { 2 - 10 } & Coal & Crude Oil & $\begin{array}{c}\text { Natural } \\
\text { Gas }\end{array}$ & $\begin{array}{c}\text { Hydro-, Nuclear-, } \\
\text { and Wind Power }\end{array}$ & Coal & $\begin{array}{c}\text { Crude } \\
\text { Oil }\end{array}$ & $\begin{array}{c}\text { Natural } \\
\text { Gas }\end{array}$ & $\begin{array}{c}\text { Hydro-, Nuclear-, } \\
\text { and Wind Power }\end{array}$ \\
\hline 1990 & 76.2 & 16.6 & 2.1 & 5.1 & 74.2 & 19.0 & 2.0 & 4.8 \\
1995 & 74.6 & 17.5 & 1.8 & 6.1 & 75.3 & 16.6 & 1.9 & 6.2 \\
2000 & 69.2 & 22.2 & 2.2 & 6.4 & 73.2 & 17.2 & 2.7 & 6.9 \\
2005 & 70.8 & 19.8 & 2.6 & 6.8 & 77.6 & 12.0 & 3.0 & 7.4 \\
2010 & 68.0 & 19.0 & 4.4 & 8.6 & 76.6 & 9.8 & 4.2 & 9.4 \\
2017 & 60.4 & 18.8 & 7 & 13.8 & 69.6 & 7.6 & 5.4 & 17.4 \\
$2017 / 1990$ & 0.79 & 1.13 & 3.33 & 2.71 & 0.94 & 0.40 & 2.70 & 3.63 \\
\hline
\end{tabular}

Source: China Statistical Yearbook (2018)

\subsection{ICT infrastructure}

Digitalization and ICT is a growing phenomenon in China and providing many business opportunities in various areas. It includes cloud technology, enterprise services, IC design, E-commerce and E-finance, mobile components and embedded software, big data, and app-based ICT platforms. At the core of the Chinese government's 12th Five-year plan, the ICT sector represents the largest single market in the world. 


\section{INSIGHTS INTO REGIONAL DEVELOPMENT}

ISSN 2669-0195 (online) http://jssidoi.org/jesi/

2021 Volume 3 Number 2 (June)

http://doi.org/10.9770/IRD.2021.3.2(1)

Following the 19th Party Congress - on developing internet technologies for artificial intelligence (AI), internet of things (IoT), big data, cloud, and mobiles as new engines of growth - the Chinese leadership stressed that the information \& communication technologies (ICT), as well as the digital economy, underpin the country's economic development. "Without information, there is no modernization" is the slogan that captured the highlevel attention in China. Chinese internet, as well as other companies, has been growing enormously and became more influential because the private sector and state are financing them with needed capital both inside and outside of the country. Additionally, the digital economy became an integral part of daily life in China. The entrepreneurs create new business applications and technologies that support and bring innovation into the day to day activities and routine work.

Ministry of Industry and Information Technology (MIIT) is responsible for regulation about wire signals, the internet broadcasting \& communication system, software, and electronic goods. Through the sustainability and introduction of proper regulations; now, more and more Chinese access the internet in their mobile phones. The usage of smartphones and other IT types of equipment resulted in less investment in fixed-line telephones and a more considerable amount of investment in more advanced technologies. Similarly, the introduction of these technologies enabled Chinese people to do many smart things like E-commerce, online shopping, etc.

During 2006, China announced the 2006-2020 National Informatization Development Strategy. The strategy focuses on the role of informatization as the engine for industrialization. It is characterized to achieve an increase in productivity, ensure sustainable development, low environmental pollution, high economic efficiency, and low consumption of materials. Moreover, the strategy is the plan to boost domestic companies and make them global champions by bringing indigenous innovative core technologies rather than imitating and introducing it from abroad. Additionally, the strategy is focusing on the establishment of a world-leading, safe, and reliable information system. The opportunities for domestic companies include information and innovative technologies. It will bring forth new ideas and know-how that may enhance the capabilities of the business entities to introduce a more sophisticated, diversified, and complex product. That may, in turn, lead to the overall sophistication of the economy. China also operates five-year plans. The latest five-year plan mainly focuses on e-logistic, e-commerce, traceability of agricultural products, epidemic surveillance, smart healthcare, and smart transportation system.

The sub-sectors of ICT in China include telecoms, hardware, and software. There are three big players in the telecom industry, i.e., China Unicom, China Telecom, and China Mobiles which share the Chinese market by $23 \%, 14 \%$, and 63\% respectively. During 2015, the total mobile subscribers concerning the telecom sector were 1292 million while there were $5503 \mathrm{G}$ subscribers. Regarding the hardware sector, the leading domestic players include Lenovo, Huawei, Founder, Haier, Xiaomi, etc. while the foreign companies consist on IBM, HP, Dell, Apple, Cisco, and ARM. Chinese domestic companies make joint ventures and other kinds of partnerships with big foreign technology giants and make different kinds of hardware like integrated circuits (IC), broadband routers, health-tech devices, internet of thing (IoT), high-tech casings, etc. During the third quarter of 2018, the revenue of China's software industry revenue increased by $15 \%$ to reach 647.4 billion. The software industry in China is composed of sub-sectors like a software product, system integration, operation service, embedded software, IT consulting, and IC design. Moreover, domestic firms in this sector consist of Kingdee, Huawei, and Neusoft, while foreign enterprises include Microsoft, Apple, SAP, Cisco, and Oracle.

In 2016 China's ICT exports account for $26.49 \%$ in total exports, the portion of ICT imports estimates $23.75 \%$ for total imports, and in 2017 the mobile cellular subscriptions accounted for 1.47 billion. Moreover, China's GDP growth is $6.9 \%$ in 2017, which is quite useful for such a huge economy. The Chinese annual growth of the big data market is $30 \%$. 
INSIGHTS INTO REGIONAL DEVELOPMENT

ISSN 2669-0195 (online) http://jssidoi.org/jesi/

2021 Volume 3 Number 2 (June)

http://doi.org/10.9770/IRD.2021.3.2(1)

\section{Model and data}

\subsection{Model}

The underlying concern of our study is to show the relationship between FDI and infrastructure as specified by earlier literature, i.e. (Asiedu, 2002; Cheng \& Kwan, 2000; Flores \& Aguilera, 2007; Loree \& Guisinger, 1995; Wheeler \& Mody, 1992). Therefore, we can construct our baseline models like the following:

$$
F D I=f(I N F, I Q, \mathrm{TO}, \mathrm{DI}),
$$

Here the terms FDI, INF, IQ, TO, DI represent the foreign direct investment, infrastructure, institutional quality, trade openness, and domestic investment respectively. The term $\mathrm{X}$ represents the control variables we include in different specifications.

The objective of our study is to show the link between FDI and infrastructure. Foreign firms make those countries as the destination where there is well-developed infrastructure, so that MNEs may smoothly run business activities and obtain better returns on their investments. Similarly, the spillover effects of foreign investment bring forth the development of necessary infrastructure.

According to Shatz and Venables (2000), the motive for MNCs to invest abroad include better serving the local market. This is called 'horizontal' or 'market seeking' (market access motivation) FDI to have access to lowercost inputs. The first motive is mainly driven by market size. This is a substitute for international trade that implies a duplication of production plants, i.e., to economize on tariffs, transport costs and to tap a new market. Since there is fragmentation, therefore, the second motive for MNCs is to have access to lower-cost inputs. It is called 'production cost-minimizing FDI' or 'vertical FDI' (resource access motivation). Infrastructure is like an amenity that can help in reducing the cost of production. Hence it is believed that it has relatively more influence on vertical FDI though it also has an impact on horizontal FDI.

Khadaroo and Seetanah (2008) argue that the reduction of transport cost and an increase in accessibility are related to the development of infrastructure. The public infrastructure helps to maximize profit and reduce the cost of doing business for multinational corporations. Therefore, the infrastructure helps the businesses in the reduction of costs through the facilitation of the production process. In the absence of public infrastructure, the MNCs may incur additional costs and results in reluctance in investments (Erenburg, 1993). Therefore, it is generally considered that public infrastructure in the form of transportation, ICT, energy, and finance may lower the cost of production and facilitate business activities. For example, the improved infrastructure may results in the reduction in the cost through the efficient transportations of heavy types of equipment. It also helps in the construction of new factories. Similarly, efficient communication and energy setups help in the increase in overall productivity. Contrary to this, the abnormal shutdown of electricity and inefficient communication system may lead to a burden of extra costs and is deterrent for MNCs to invest overseas. Moreover, foreign enterprises invest in developing countries to reap the benefits of lower labour costs. However, if the infrastructure is not efficient, then the firms may incur additional costs associated with transportation, electricity generation, and installation of communication setups. Similarly, the presence of well-developed infrastructure enables firms to avoid any startup costs and ensure timely delivery of materials.

The public infrastructure enables the firms to deliver the products and receive the raw materials efficiently, thereby enhances their productivity and efficiency while reduces the cost of doing business (Erenburg, 1993; Khan, Khan, Jiang, \& Khan, 2020). Additionally, the network of infrastructure and good quality of transportation 


\section{INSIGHTS INTO REGIONAL DEVELOPMENT}

ISSN 2669-0195 (online) http://jssidoi.org/jesi/

2021 Volume 3 Number 2 (June)

http://doi.org/10.9770/IRD.2021.3.2(1)

make it convenient for the business entities to avoid maintenance costs. For example, highway maintenance and better road designs can help in the reduction of transportation as well as wear and tear costs. The argument is valid for private ships and barges, which require ports and navigable waterways, and for aircraft which require airports.

The public infrastructure increases the level of output per unit of input, e.g., the scarce resources are efficiently utilized. Therefore, countries attract FDI by improving the quality and quantity of infrastructure. Hence, the investments by foreign enterprises are subsidized, and returns on their capital increase through the provision of well-developed public infrastructure. Vertical FDI takes advantage of improved public infrastructure in the form of timely supply of their output and imports of the inputs. Horizontal FDI takes advantage in the form of increased output per unit of input. Similarly, the improved infrastructure enhances access to foreign firms to tap new markets in the neighbourhood as well as in the host countries.

Location advantages that foreign firms seek before investing and operating in the host country come under the purview of good infrastructure (including communications and transportation among others)(Cantwell, 2016; Dunning \& McQueen, 1981). Therefore, the improved infrastructure can attract FDI through the provision of the environment that may ease their operations.

The empirical literature on the role of public infrastructure in firms' productivity is diverse. Previous literature suggests a positive relationship between infrastructure and productivity and a negative relationship between the cost of firms and public infrastructure (Aschauer, 1989; Nadiri \& Mamuneas, 1994). However, there is no unanimous consensus on the role of public infrastructure in productivity. Therefore, the second strand of the literature shows no effect of public infrastructure and public investment in the firms' productivity (Holtz-Eakin, 1994; Holtz-Eakin \& Schwartz, 1995). Regardless of any direct effects of public infrastructure on the productivity, there are empirical studies that show the indirect effect (spillover effect) of public investment and infrastructure (from clustering and agglomeration created by public infrastructure) on the cost and productivity of business enterprises. Moreover, the trade flow between countries is determined by the trade costs associated with public infrastructure, specifically the transport infrastructure (Limao, 2001).

Given the above theoretical overview, we are in a position to say that there are various reasons for the MNCs' presence abroad. Firstly, the output cost per unit of input applied reduces for the vertical FDI in the presence of improved public infrastructure. Secondly, horizontal FDI takes advantage in the form of increased output per unit of input.

\subsection{Data}

The basic concern of this study is to explore the relationship between infrastructure and sectoral FDI during 1988 to 2017. We apply the methodology on various indicators specified by Donaubauer et al. (2016) for the construction of our infrastructure index. We use 30 indicators and constructed a composite index. The indicators used in the construction of the Infrastructure Index based on transport (land, air, and sea transport), Internet \& Communications Technology (ICT), energy (production and consumption of energy), and financial infrastructure. The sample selection dictates to the data availability. The index is constructed, keeping in view the shortcomings in the previous literature.

In this study, we use the sectoral FDI. The data about sectoral FDI comes from the China Statistical Yearbook. The data about sectoral FDI is composed of primary (mining \& quarrying), secondary (manufacturing), and tertiary (services) sectors. We normalized FDI by GDP. So, the variables we have to show the FDI (\% of GDP). This reduces the problem of aggregation bias. Following the previous literature, we include important control 
INSIGHTS INTO REGIONAL DEVELOPMENT

ISSN 2669-0195 (online) http://jssidoi.org/jesi/

2021 Volume 3 Number 2 (June)

http://doi.org/10.9770/IRD.2021.3.2(1)

variables in our analysis to avoid the omitted variable bias. The baseline model with infrastructure and institutional quality indices greatly explain the variations in FDI.

Institutions are social, political, and economic elements that define the rules of the economies (Schout \& North, 1991). Well-developed institutions reduce transaction costs and improve efficiency (Khanna \& Rivkin, 2001; Schout \& North, 1991). We rely on the International Country Risk Guide (ICRG) data. The data consists of government effectiveness, the rule of law, bureaucratic quality, investment profile, democratic accountability, and control of corruption. The individual aspects may not portray an accurate picture of institutional quality when put in a regression. Following Buchanan et al. (2012); Globerman and Shapiro (2003), we apply Principal Component Analysis (PCA) to derive a composite index of institutional quality.

Trade openness also influences the FDI inflow into the host economies (Iamsiraroj \& Ulubaşoğlu, 2015), and domestic investment. Similarly, infrastructure is also affected by the above variables. For example, when the volume of trade and domestic investment increases, then there is a need for more public investment in infrastructure development. Trade share percent of GDP is used as a proxy for trade openness. Gross fixed capital formation (\% of GDP) is used as a proxy for domestic investment. The data about trade openness and domestic investment is extracted from World Bank (2018).

The descriptive statistics are given in Table 3. It shows the measure of central tendency and variability of the data. In this regard, we report the mean, median, standard deviation, minimum, and maximum. The mean and median values of primary FDI are close to each other with standard deviation is 0.113 , which shows that the data is less scattered. The primary FDI exhibits more stability and less variability. The stability implies that China attracted more FDI in the manufacturing and services sectors, while the FDI inflow in the primary sector increases at a very minimal rate. Therefore, we see here that FDI is services and manufacturing sectors shows more volatility and less stability. This implies that the macroeconomic environment affects the manufacturing and services FDI, which may occur due to the open door policies and infrastructure development. However, the infrastructure shows less variability based on median and mean values; however, the standard deviation is 0.382 , which shows less stability. Moreover, all variables follow a normal distribution, according to Jarque-Bera (JB) test of normality.

Table 3. Descriptive statistics

\begin{tabular}{|c|c|c|c|c|c|c|c|c|}
\hline Variables & Notation & Mean & Median & Max. & Min. & $\mathrm{SD}$ & JQ & Prob. \\
\hline FDI (\% share in GDP) & FDI & 5.05 & 3.95 & 13.32 & 2.013 & 3.36 & 4.15 & 0.12 \\
\hline FDI in the primary sector & PRI & 1.11 & 1.08 & 1.38 & 1.01 & 0.11 & 4.56 & 0.10 \\
\hline FDI in the manufacturing sector & SEC & 3.68 & 3.17 & 9.47 & 1.34 & 2.41 & 4.32 & 0.11 \\
\hline FDI in services & TER & 2.25 & 1.82 & 4.46 & 1.65 & 0.85 & 5.30 & 0.07 \\
\hline Infrastructure & INF & 1.52 & 1.57 & 2.00 & 0.59 & 0.38 & 1.83 & 0.39 \\
\hline Institutional quality & IQ & 1.18 & 1.50 & 2.43 & -1.14 & 0.94 & 3.67 & 0.15 \\
\hline Trade share in GDP $(\%)$ & TO & 43.74 & 40.43 & 65.47 & 25.27 & 11.1 & 1.56 & 0.45 \\
\hline Domestic investment share in GDP (\%) & DI & 38.92 & 40.07 & 46.51 & 25.56 & 5.89 & 1.39 & 0.49 \\
\hline
\end{tabular}

Note. One is being added to actual values. SD and JQ represent standard deviation and Jarque-Bera statistic.

\section{Method and results}




\section{INSIGHTS INTO REGIONAL DEVELOPMENT}

ISSN 2669-0195 (online) http://jssidoi.org/jesi/

2021 Volume 3 Number 2 (June)

http://doi.org/10.9770/IRD.2021.3.2(1)

In this study, we apply the autoregressive distributive (ARDL) technique of cointegration, developed by Pesaran et al. (2001). There are several advantages to use the ARDL approach. First, the method is applicable irrespective of the order of integration of variables, i.e., $\mathrm{I}(0), 1(1), 1(1,0)$. If the variables are $\mathrm{I}(2)$ or above, then the F-statistics is not invalid (Ouattara, 2006). Second, ARDL is applicable in case some of the regressors are endogenous (Odhiambo, 2009). Third, the method is effective even in the case of small samples (Ghatak \& Siddiki, 2001). In case of small samples, the method is better than Johansen and Juselius (Johansen, 1991), Engle \& Granger (Engle \& Granger, 2015), and Phillips and Hansen (Phillips \& Hansen, 1990). Another advantage of using ARDL is that it overcomes the problems resulting from series with unit roots and the unrestricted error correction model (UECM) seems to take satisfactory lags that captures the data generating process in a general-to-specific framework of specification (Kinkyo, Matsubayashi, \& Hamori, 2013). We aim to investigate the causal relationship between sectoral FDI and infrastructure across different specifications.

Before the estimation of the empirical results, it is imperative to determine the order of integration. In this regard, we use Augmented Dicky Fuller (ADF) test. We also apply the Phillips- Perron (PP) test in order to get robust results. Moreover, we also apply the Zivot-Andrews breakpoint unit root test in order to avoid misleading and biased results. We follow Ayala and Triguero (2017) and apply Baum's modified methodology for unit root testing against the alternative of trend stationarity with a shift in time trend, shift in mean, and a shift in both slope and intercept.

Table 4 reports the results of the unit root. All the tests show that none of our variables is integrated of $\mathrm{I}(2)$. Similarly, there is mix integration of variables, i.e., some variables are integrated of $\mathrm{I}(0)$ while others are $\mathrm{I}(1)$. Moreover, the response variable is integrated of order I(1), which satisfied the precondition specified by Pesaran et al., (2001).

Table 4. Unit root and stationary test results

\begin{tabular}{|c|c|c|c|c|c|c|c|c|c|c|}
\hline \multirow[t]{2}{*}{ Variable } & \multicolumn{2}{|c|}{$\mathrm{ADF}$} & \multicolumn{2}{|c|}{ Phillips- Perron } & \multicolumn{6}{|c|}{ Zivot-Andrews } \\
\hline & $\mathrm{I}(0)$ & $\mathrm{I}(1)$ & $\mathrm{I}(0)$ & $\mathrm{I}(1)$ & $\mathrm{Zd}$ & Break & $\mathrm{Zt}$ & Break & $\mathrm{Zdt}$ & Break \\
\hline FDI & -3.003 & $-4.32 * *$ & $-3.62 * *$ & $-4.26 * *$ & -3.111 & 2014 & $-5.173 * * *$ & 1994 & -4.106 & 2009 \\
\hline IQ & -1.853 & $-5.22 * * *$ & $-3.35^{*}$ & $-5.49 * * *$ & -3.723 & 1995 & -3.832 & 1999 & -4.8 & 2001 \\
\hline DI & $-3.83 * *$ & $-3.71 * *$ & -2.264 & $-3.52 *$ & -4.497 & 2015 & $-4.717 * *$ & 2014 & $-5.839 * * *$ & 2011 \\
\hline
\end{tabular}

Note. $* \mathrm{p}<0.10, * * \mathrm{p}<0.05, * * * \mathrm{p}<0.01$. ADF and PP tests include intercept and trend. The ZA tests are the minimum Dicky-Fuller statistics with one structural break in intercept $(\mathrm{Zd})$, trend $(\mathrm{Zt})$, and both intercept and trend (Zdt). Break indicates the year when minimum DF statistic is obtained.

The next step is to apply the ARDL (autoregressive distributed lag) bounding testing procedure of cointegration. The bound test provides us with F-statistics whether cointegration exists or not. If the F-statistic value is higher than upper-bound, then there is cointegration. Similarly, the values of the F-statistic below the lower bound value indicate no cointegration. While the F-statistic value between the upper and lower bound indicate inconclusive region.

In order to investigate the relationship between infrastructure and foreign direct investment, we can formulate the unrestricted error correction model (ECM) as the following; 


$$
\begin{aligned}
& \Delta F D I_{t}=\alpha_{0 f d i}+\sum_{i=1}^{p} \psi_{i f d i} \Delta F D I_{t-i}+\sum_{i=1}^{p} \rho_{i f d i} \Delta I N F_{t-i}+\sum_{i=1}^{p} \phi_{i f d i} \Delta I Q_{t-i}+\sum_{i=1}^{p} \delta_{i f d i} \Delta T O_{t-i}+\sum_{i=1}^{p} \rho_{i f d i} \Delta D I_{t-i}+\lambda_{1 f d i} F D I_{t-1} \\
& +\lambda_{2 f d i} I N F_{t-1}+\lambda_{3 f d i} I Q_{t-1}+\lambda_{4 f d i} T O_{t-1}+\lambda_{5 f d i} D I_{t-1}+\mu_{1 t}------E q u a t i o n(2) \\
& \Delta I N F_{t}=\alpha_{0 \mathrm{inf}}+\sum_{i=1}^{p} \psi_{i \mathrm{inf}} \Delta I N F_{t-i}+\sum_{i=1}^{p} \phi_{i \mathrm{inf}} \Delta F D I_{t-i}+\sum_{i=1}^{p} \rho_{i \mathrm{inf}} \Delta I Q_{t-i}+\sum_{i=1}^{p} \delta_{i \mathrm{inf}} \Delta T O_{t-i}+\sum_{i=1}^{p} \rho_{i \mathrm{inf}} \Delta D I_{t-i} \\
& +\lambda_{\text {linf }} I N F_{t-1}+\lambda_{2 \mathrm{inf}} F D I_{t-1}+\lambda_{\text {inf }} I Q_{t-1}+\lambda_{4 \mathrm{inf}} T O_{t-1}+\lambda_{5 \mathrm{inf}} D I_{t-1}+\mu_{2 t}----- \text { Equation(3) }
\end{aligned}
$$

In Eq. (2) the term FDI is the foreign direct investment. Similarly, the dependent variable in the Eq. (3) is represented by INF. To have in-depth analysis, we repeat the same methodology by replacing the aggregate FDI with sectoral FDI, i.e., PRI (Primary), SEC (Manufacturing), TER (Services sector) in the above equations. We use institutional quality, trade openness, and domestic investment as controlled variables. The subscript $t$ is the time dimension. ARDL technique is applied to the model for identification of the long- and short-run dynamics. Pesaran et al. (2001) provided upper and lower bound critical values. However, the values are applicable for large samples. In the case of small samples, the decision based on the Pesaran et al. (2001) critical values can mislead the estimation results (Herzer, 2010). If the computed F-statistic falls above the upper value bound, the null is rejected, indicating cointegration. If the computed F-statistic falls below the lower bound, the null hypothesis of no cointegration is accepted. In contrast, if the computed F-statistic falls within the bounds, the inference would be inconclusive.

The significant F-statistics of the estimated ARDL bound test in Table 5 both for foreign direct investment and infrastructure as dependent variables, reject the null of no cointegration. This implies that a stable long-run relationship between FDI and infrastructure exist at aggregate as well as sectoral level.

Table 5. ARDL bounds test results

\begin{tabular}{|lll|lll|}
\hline FDI as dependent variable & & & INF as dependent variable & \\
\hline Models & Max lag. & F-Statistics & Models & Max lag. & F-Statistics \\
\hline F(FDI/INF, IQ, ,TO, DI) & $(3,1,3,3,3)$ & $13.49 * * *$ & F(INF/FDI, IQ,TO, DI) & $(1,2,3,2,2)$ & $13.09 * * *$ \\
F(PRI/ INF, IQ, TO, DI) & $(3,0,3,3,1)$ & $4.873^{* *}$ & F(INF/PRI, IQ,TO, DI) & $(3,1,3,0,0)$ & $5.496 * *$ \\
F(SEC/ INF, IQ,TO, DI) & $(3,3,3,3,0)$ & $5.73^{* *}$ & F(INF/SEC, IQ,TO, DI) & $(1,2,3,3,3)$ & $10.71 * * *$ \\
F(TER/ INF, IQ,TO, DI) & $(2,3,2,0,2)$ & $4.63 * *$ & F(INF/TER, IQ,TO, DI) & $(3,3,1,0,2)$ & $12.39 * * *$ \\
\hline
\end{tabular}

Note. ${ }^{*} \mathrm{p}<0.10, * * \mathrm{p}<0.05, * * * \mathrm{p}<0.01$. The first letter outside the brackets denotes dependent variables. The null hypothesis of no cointegration is tested with F-test, critical values are taken from Narayan (2005). Lag selection is based on the AIC. For upper and lower bound critical value; please see Appendix , Table A1

Hence, we generalize that there is a long-run relationship between FDI and infrastructure. We check the cointegration in Johansen Johansen multivariate cointegration framework in order to check for robustness. The results are given in Table 6 . We see that there are three cointegrating vectors which validate the presence of a long-run relationship between the variables, which indicate the ARDL results are robust and reliable.

Table 6. The Johansen cointegration analysis.

\begin{tabular}{|l|ll|}
\hline Hypothesis & Trace statistic & Max.eigen value \\
\hline$R=0$ & $170.4004 * * *$ & $83.64441 * * *$ \\
$R \leq 1$ & $86.75601 * * *$ & $39.01881 * * *$ \\
$R \leq 2$ & $47.7372 * * *$ & $26.90004 * * *$
\end{tabular}


INSIGHTS INTO REGIONAL DEVELOPMENT

ISSN 2669-0195 (online) http://jssidoi.org/jesi/

2021 Volume 3 Number 2 (June)

http://doi.org/10.9770/IRD.2021.3.2(1)

\begin{tabular}{|l|ll|}
$R \leq 3$ & $20.83716^{* * *}$ & $16.08317^{* *}$ \\
$R \leq 4$ & $4.753994 * *$ & $4.753994 * *$ \\
\hline
\end{tabular}

Note. $* \mathrm{p}<0.10, * * \mathrm{p}<0.05, * * * \mathrm{p}<0.01$

In the next step we reparametrize the equations that show cointegration. For this purpose, the following ARDL framework is presented;

$\left(1-\Omega_{1} L-\ldots-\Omega_{s} L^{s}\right) F D I_{t}=\tau_{0}+\left(1-\tau_{1} L-\ldots-\tau_{u} L^{u}\right) I N F+\left(1-\gamma_{1} L-\ldots-\gamma_{v} L^{v}\right) I Q+\left(1-\pi_{1} L-\ldots-\pi_{w} L^{w}\right) \mathrm{TO}$

$+\left(1-\varnothing_{1} L-\ldots-\varnothing_{x} L^{x}\right) D I+\mu_{3 t}------$ Equation $(4)$

$\left(1-\Omega_{1} L-\ldots-\Omega_{s} L^{s}\right) I N F_{t}=\tau_{0}+\left(1-\tau_{1} L-\ldots-\tau_{u} L^{u}\right) F D I+\left(1-\gamma_{1} L-\ldots-\gamma_{v} L^{v}\right) I Q+\left(1-\pi_{1} L-\ldots-\pi_{w} L^{w}\right) \mathrm{TO}$

$+\left(1-\varnothing_{1} L-\ldots-\varnothing_{x} L^{x}\right) D I+\mu_{4 t}------E q u a t i o n(5)$

In the next step, we reparametrize Eq.(4) to (5). The step is done to obtain long-run coefficient estimates by including those equations that show cointegration. The long-run relationship from infrastructure to FDI and vice versa is presented in Table 6. The results reveal that infrastructure coefficients in all the specifications are significant and positive, which implies that infrastructure positively influences FDI inflow. Similarly, the reverse impact also holds. Coefficients of FDI (aggregated as well as sectoral) are significant and positive, which shows that FDI inflow is one of the reasons that boosted up the infrastructure in China. The reports of control variables are according to the economic theory and prior expectations. The diagnostic results show that our models are correctly specified (see Table 7).

Table 7. Results on Long-Run Effect

\begin{tabular}{|c|c|c|c|c|c|c|c|c|c|c|c|}
\hline \multirow{2}{*}{$\begin{array}{l}\text { Dependent } \\
\text { variable }\end{array}$} & \multirow{2}{*}{ Cons. } & \multirow{2}{*}{$\begin{array}{l}\mathrm{INF} / \mathrm{F} \\
\mathrm{DI}\end{array}$} & \multirow{2}{*}{ IQ } & \multirow{2}{*}{ TO } & \multirow{2}{*}{ DI } & \multirow{2}{*}{ F-stat. } & \multicolumn{2}{|c|}{ LM Test } & \multirow{2}{*}{$\begin{array}{l}\text { Hetero } \\
\text { (Arch } \\
\text { test) }\end{array}$} & \multirow{2}{*}{$\begin{array}{l}\text { Ramsey } \\
\text { Reset } \\
\text { Test }\end{array}$} & \multirow{2}{*}{ JQ } \\
\hline & & & & & & & AR1 & AR2 & & & \\
\hline \multicolumn{12}{|c|}{ Panel A. INF to FDI } \\
\hline FDI & $\begin{array}{l}6.60 * * * \\
(1.45)\end{array}$ & $\begin{array}{l}0.18^{*} \\
(0.1)\end{array}$ & $\begin{array}{l}0.10 * * * \\
(0.02)\end{array}$ & $\begin{array}{l}0.02 \\
(0.02)\end{array}$ & $\begin{array}{l}0.05 * * \\
(0.02)\end{array}$ & $\begin{array}{l}114.89 \\
(0.00)\end{array}$ & $\begin{array}{l}1.13 \\
(0.28)\end{array}$ & $\begin{array}{l}2.37 \\
(0.31)\end{array}$ & $\begin{array}{l}2.26 \\
(0.13)\end{array}$ & $\begin{array}{l}1.91 \\
(0.27)\end{array}$ & $\begin{array}{l}0.17 \\
(0.92)\end{array}$ \\
\hline PRI & $\begin{array}{l}9.112 * * * \\
(1.78)\end{array}$ & $\begin{array}{l}0.07 * * \\
* \\
(0.02)\end{array}$ & $\begin{array}{r}0.021 \\
(0.12)\end{array}$ & $\begin{array}{l}0.01 \\
(0.02)\end{array}$ & $\begin{array}{l}0.112^{*} \\
(0.05)\end{array}$ & $\begin{array}{l}100.46 \\
(0.00)\end{array}$ & $\begin{array}{l}2.64 \\
(0.10)\end{array}$ & $\begin{array}{l}3.70 \\
(0.15)\end{array}$ & $\begin{array}{l}0.015 \\
(0.91)\end{array}$ & $\begin{array}{l}1.32 \\
(0.37)\end{array}$ & $\begin{array}{l}0.93 \\
(0.63)\end{array}$ \\
\hline SEC & $\begin{array}{l}5.08 * * \\
(1.99)\end{array}$ & $\begin{array}{l}0.72 * * \\
(0.37)\end{array}$ & $\begin{array}{l}0.19 \\
(0.17)\end{array}$ & $\begin{array}{l}0.02 \\
(0.02)\end{array}$ & $\begin{array}{l}0.04 * \\
(0.02)\end{array}$ & $\begin{array}{l}17.071 \\
(0.00)\end{array}$ & $\begin{array}{l}1.98 \\
(0.15)\end{array}$ & $\begin{array}{l}2.44 \\
(0.12)\end{array}$ & $\begin{array}{l}2.28 \\
(0.13)\end{array}$ & $\begin{array}{l}0.49 \\
(0.7)\end{array}$ & $\begin{array}{l}0.33 \\
(0.85)\end{array}$ \\
\hline TER & $\begin{array}{l}0.79 \\
(1.18) \\
\end{array}$ & $\begin{array}{l}0.1 * * * \\
(0.03)\end{array}$ & $\begin{array}{l}0.24 * * * \\
(0.06) \\
\end{array}$ & $\begin{array}{l}0.02 * \\
(0.01)\end{array}$ & $\begin{array}{l}0.06 * * \\
(0.03)\end{array}$ & $\begin{array}{l}11.402 \\
(0.00)\end{array}$ & $\begin{array}{l}1.51 \\
(0.23) \\
\end{array}$ & $\begin{array}{l}1.05 \\
(0.31) \\
\end{array}$ & $\begin{array}{l}1.58 \\
(0.21) \\
\end{array}$ & $\begin{array}{l}1.44 \\
(0.3) \\
\end{array}$ & $\begin{array}{l}0.33 \\
(0.85) \\
\end{array}$ \\
\hline \multicolumn{12}{|c|}{ Panel B. FDI to INF } \\
\hline $\mathrm{F}(\mathrm{INF} / \mathrm{FDI})$ & $\begin{array}{l}-12.25 * * * \\
(3.09)\end{array}$ & $\begin{array}{l}1.158^{*} \\
(0.65)\end{array}$ & $\begin{array}{l}0.081 \\
(0.09)\end{array}$ & $\begin{array}{l}-0.04^{*} \\
(0.02)\end{array}$ & $\begin{array}{l}0.02 * * \\
(0.01)\end{array}$ & $\begin{array}{l}78.245 \\
(0.00)\end{array}$ & $\begin{array}{l}0.39 \\
(0.53)\end{array}$ & $\begin{array}{l}2.27 \\
(0.13)\end{array}$ & $\begin{array}{l}2.06 \\
(0.15)\end{array}$ & $\begin{array}{l}3.13 \\
(0.1)\end{array}$ & $\begin{array}{l}0.16 \\
(0.92)\end{array}$ \\
\hline $\mathrm{F}(\mathrm{INF} / \mathrm{PRI})$ & $\begin{array}{l}-1.25 \\
(2.3)\end{array}$ & $\begin{array}{l}0.15 * * \\
(0.05)\end{array}$ & $\begin{array}{l}0.11 \\
(0.07)\end{array}$ & $\begin{array}{l}-0.05^{*} \\
(0.02)\end{array}$ & $\begin{array}{l}0.03 * * \\
(0.01)\end{array}$ & $\begin{array}{l}64.122 \\
(0.00)\end{array}$ & $\begin{array}{l}2.41 \\
(0.12)\end{array}$ & $\begin{array}{l}1.42 \\
(0.23)\end{array}$ & $\begin{array}{l}0.007 \\
(0.93)\end{array}$ & $\begin{array}{l}0.69 \\
(0.59)\end{array}$ & $\begin{array}{l}1.52 \\
(0.47)\end{array}$ \\
\hline $\mathrm{F}(\mathrm{INF} / \mathrm{SEC})$ & $\begin{array}{l}-1.01 \\
(3.37)\end{array}$ & $\begin{array}{l}0.79 * \\
(0.43)\end{array}$ & $\begin{array}{l}0.08 \\
(0.06)\end{array}$ & $\begin{array}{l}0.01 \\
(0.01)\end{array}$ & $\begin{array}{l}0.05 * * \\
* \\
(0.01)\end{array}$ & $\begin{array}{l}57.545 \\
(0.00)\end{array}$ & $\begin{array}{l}2.7 \\
(0.10)\end{array}$ & $\begin{array}{l}2.26 \\
(0.13)\end{array}$ & $\begin{array}{l}2.15 \\
(0.14)\end{array}$ & $\begin{array}{l}1.36 \\
(0.36)\end{array}$ & $\begin{array}{l}0.86 \\
(0.65)\end{array}$ \\
\hline $\mathrm{F}(\mathrm{INF} / \mathrm{TER})$ & $\begin{array}{l}2.51 \\
(1.57) \\
\end{array}$ & $\begin{array}{l}0.09 * \\
(0.05) \\
\end{array}$ & $\begin{array}{l}0.27 * * * \\
(0.07) \\
\end{array}$ & $\begin{array}{l}0.01 \\
(0.01) \\
\end{array}$ & $\begin{array}{l}0.02 * \\
(0.01) \\
\end{array}$ & $\begin{array}{l}67.612 \\
(0.00) \\
\end{array}$ & $\begin{array}{r}1.84 \\
(0.17) \\
\end{array}$ & $\begin{array}{r}2.57 \\
(0.11) \\
\end{array}$ & $\begin{array}{r}0.06 \\
(0.81) \\
\end{array}$ & $\begin{array}{l}2.17 \\
(0.17) \\
\end{array}$ & $\begin{array}{l}2.34 \\
(0.31) \\
\end{array}$ \\
\hline
\end{tabular}

Note. $* \mathrm{p}<0.10, * * \mathrm{p}<0.05, * * * \mathrm{p}<0.01$. Values in parenthesis of coefficients represent standard error. Values in parenthesis in diagnostic panel represent p-values and values outside parenthesis are F-statistics. All the estimated models are stable.

If the long-run relationship exists (the necessary condition for cointegration but not a sufficient condition) then under the VECM environment, granger causality test show long-run and short-run causality for the two variables. 
Under the VAR framework, traditional Granger causality test can produce ambiguous results; therefore, under the VECM framework the following is its improved version;

$$
\begin{aligned}
& \Delta F D I_{t}=\alpha_{0 f d i}+\sum_{i=1}^{p} \psi_{i f d i} \Delta F D I_{t-i}+\sum_{i=1}^{p} \rho_{i f d i} \Delta I N F_{t-i}+\sum_{i=1}^{p} \phi_{i f d i} \Delta I Q_{t-i}+\sum_{i=1}^{p} \delta_{i f d i} \Delta T O_{t-i}+\sum_{i=1}^{p} \delta_{i f d i} \Delta D I_{t-i}+\Omega_{1} E C T_{t-1} \\
& +\mu_{5 t}------ \text { Equation(6) } \\
& \Delta I N F_{t}=\alpha_{0 f d i}+\sum_{i=1}^{p} \psi_{i f d i} \Delta I N F_{t-i}+\sum_{i=1}^{p} \rho_{i f d i} \Delta F D I_{t-i}+\sum_{i=1}^{p} \phi_{i f d i} \Delta I Q_{t-i}+\sum_{i=1}^{p} \delta_{i f d i} \Delta T O_{t-i}+\sum_{i=1}^{p} \delta_{i f d i} \Delta D I_{t-i}+\Omega_{2} E C T_{t-1} \\
& +\mu_{6 t}------ \text { Equation }(7)
\end{aligned}
$$

To reach in long-run equilibrium for the variables INF and FDI; ECTs (error correction term) are the speed of adjustment. The significant value of F-statistics indicates that short-run causality exists between the two variables, whereas the significant value of $\mathrm{t}$-statistics for $\mathrm{ECT}_{\mathrm{t}-1}$ indicates the long-run causality.

The results of the VECM are given in Table 8. The long-run relationship is confirmed by the ECT terms that are significantly negative in FDI equations. The long-run ECT is the speed of adjustment to restore equilibrium. Similarly, ECT terms are significantly negative in all the INF equations; except in the equations where we use primary FDI as an independent variable. Here we note that there is a long-run bidirectional causal relationship between infrastructure and FDI at aggregate, manufacturing, and service sector FDI. The significant value of Fstatistics determines the short-run causality. The causality is determined by the F-statistics to test the joint significance of all the lagged first differences of independent variables (Ali \& Wang, 2018; Lee, 2010; Zhang,

\begin{tabular}{|c|c|c|c|c|c|}
\hline \multicolumn{3}{|l|}{ INF to FDI } & \multicolumn{3}{|l|}{ FDI to INF } \\
\hline Dependent variable & $\begin{array}{l}\text { Short-run F-stat } \\
\Delta(\mathrm{INF}, \mathrm{IQ}, \mathrm{TO}, \mathrm{DI})\end{array}$ & $E C T_{(t-1)}$ & Dependent variable & $\begin{array}{l}\text { Short-run F-stat } \\
\Delta(\mathrm{FDI}, \mathrm{IQ}, \mathrm{TO}, \mathrm{DI})\end{array}$ & $E C T_{(t-1)}$ \\
\hline$\Delta \mathrm{FDI}$ & $5.74 * *$ & $-0.55^{* *}$ & $\Delta \mathrm{INF}$ & $6.4 * * *$ & $-0.286 * *$ \\
\hline$\Delta \mathrm{PRI}$ & $4.22 * *$ & $-0.19 *$ & $\Delta \mathrm{INF}$ & 3.09 & $-0.395 * *$ \\
\hline$\triangle \mathrm{SEC}$ & $4.6^{* *}$ & $-0.263 * *$ & $\Delta \mathrm{INF}$ & $4.71 * *$ & $-0.497 * *$ \\
\hline$\Delta$ TER & $6.62 * * *$ & $0.33 * *$ & $\Delta \mathrm{INF}$ & $13.98 * * *$ & $-0.445 * *$ \\
\hline
\end{tabular}
2001). We see that short-run bidirectional causality exists between INF with FDI, SEC, and TER. However, we see unidirectional causality running from infrastructure to primary FDI.

Table 8. Granger causality results

Notes: The symbol***,** and $*$ indicate significance at $1 \%, 5 \%$, and $10 \%$ respectively

The open-door policies and transitional reforms enable China to attract massive FDI in various sectors. We sum the sectors into a three strata industrial level, i.e., primary, manufacturing, and services. The above result reveals that primary, services-oriented and manufacturing industries attract more efficiency- and market-seeking FDI. Through the forward and backward linkages, the foreign inventors make their entries into the host economies.

Moreover, the size of the Chinese middle class is booming. Therefore, the Chinese government is keen on developing and maintaining the supply-side structural reforms along with the infrastructure arrangements to attract foreign investor in the service sector. The development of the services sector was a strategic priority in the 12th Five-Year Plan (2011-2015) of the Chinese Government. The well-developed infrastructure framework increases productivity and efficiency. Therefore, the Chinese government should take a keen interest in developing the infrastructure. The massive FDI inflows carry spillover effects. These effects may not be reversed in the presence of poor institutional quality (Feldstein, 2000; Loungani \& Razin, 2001). Therefore, well- 


\section{INSIGHTS INTO REGIONAL DEVELOPMENT}

ISSN 2669-0195 (online) http://jssidoi.org/jesi/

2021 Volume 3 Number 2 (June)

http://doi.org/10.9770/IRD.2021.3.2(1)

developed institutions should also be one of the priorities of the Chinese government. On the primary sector level, the peasantry is still meaningful large since the economic reforms in 1978 and with the restoration of private property rights. Similarly, intellectual property rights, joint-venture laws, contract enforcement, and other institutional reforms are introduced to attract FDI in manufacturing sectors.

In a nutshell, we see here that infrastructure plays a vital role in the sectoral distribution of foreign direct investment. We find that the impact of infrastructure in stronger in the manufacturing sector than the agriculture and services sectors. Due to the massive FDI inflows, the Chinese government spends more on infrastructure. Therefore, we see that infrastructure in energy, transport, ICT, and the financial sector is enhanced due to the foreign enterprises' presence of in these sectors like Volkswagen AG, AT\&T Corp., Citibank, Morgan Stanley \& Co., France's Citreon, Microsoft, Philips Electronics, etc. The findings are consistent with the view that multinationals have significant complementarities with local industry and may stimulate development in host economies (Markusen \& Venables, 1999). China's rate of return on capital, an essential measure of investment efficiency, far outstrips than that of the most developed countries. MNCs motivate to invest in China due to efficient infrastructure, which increases in the rate of return on their investment.

\section{Conclusion}

Globalization and open-door policies boosted Chinese economy by attracting a huge amount of foreign direct investment. Similarly, in the meantime, the infrastructure also developed at the same time. Therefore, a natural question arises as to whether the FDI inflow is complementary to the infrastructural development or other factors explain the scenario? Similarly, we also investigate the role of infrastructure in the sectoral distribution of FDI.

Previous literature focuses on the impact of infrastructure on aggregate FDI at a macro level or cross-country analysis. Keeping in view the FDI-infrastructure relationship, the previous literature focused on a single aspect on infrastructure like transport, internet, ICT (internet \& telecommunications) railways, etc. We, for the first time, contribute the existing literature by investigating the role of infrastructure in the sectoral distribution of FDI in China. Similarly, for the first time, we contribute the literature by investigating the effect of FDI inflows on infrastructure development. The earlier literature ignores the institutional quality, which may affect the FDIinfrastructure relationship in emerging countries like China.

Applying the ARDL cointegration technique, we came to know that there is a long-run bidirectional relationship between infrastructure and FDI. We also found that infrastructure positively affects the sectoral distribution of FDI in China. However, the extent of the impact of infrastructure on secondary sector FDI is more than the services sector and primary sector FDI. We also find short-run bidirectional causality between FDI (aggregate, secondary, and services). However, our results reveal unidirectional causality between primary sector FDI and infrastructure. The causality is running from infrastructure to primary FDI.

China's rapid integration into the world economy and her open-door policy has potential implications. To enhance the FDI inflow; there should be good infrastructure so that the MNCs can reap the benefits of improved efficiency, productivity, and rate of return on their investments. Since multinationals spend a huge amount on R\&D activities, therefore, investment promotion policies should be in place to harness FDI to increase productivity and efficiency of the domestic firms. Investment Promotion is quite effective in increasing inflows of FDI. Similarly, most of the spillovers occur through interactions between multinationals and their local suppliers. Therefore, the following policy should be the supplier development programs. Better financial institutions and financial infrastructure can attract more FDI through the allocative channel, transaction cost reduction, enforcement contract, and liquidity. So the financial reforms should be introduced to facilitate the smooth functioning of the economy in general and investment in specific. 
INSIGHTS INTO REGIONAL DEVELOPMENT

ISSN 2669-0195 (online) http://jssidoi.org/jesi/

2021 Volume 3 Number 2 (June)

http://doi.org/10.9770/IRD.2021.3.2(1)

Disclosure statement

The authors report no potential conflict of interest.

Aknowledgement

All the authors equally contributed in this research.

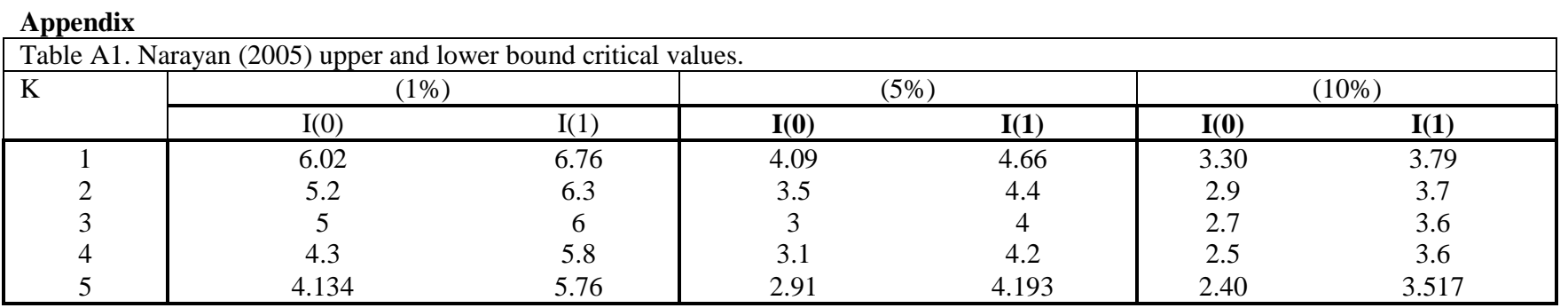

Note: Critical values for the bounds test: Case II: restricted intercept and no trend. 'K' represents number of regressors

\section{References}

Ali, U., \& Wang, J. J. (2018). Does Outbound Foreign Direct Investment Crowd Out Domestic Investment in China? Evidence from Time Series Analysis. Global Economic Review. https://doi.org/10.1080/1226508X.2018.1492431

Aschauer, D. A. (1989). Public investment and productivity growth in the Group of Seven. Economic Perspectives Provided by Federal Reserve Bank of Chicago.

Asiedu, E. (2002). On the determinants of foreign direct investment to developing countries: Is Africa different? World Development. https://doi.org/10.1016/S0305-750X(01)00100-0

Ayala, L., \& Triguero, A. (2017). Economic Downturns, Endogenous Government Policy and Welfare Caseloads. Revista Hacienda Pública Española. https://doi.org/10.7866/hpe-rpe.17.1.4

Buchanan, B. G., Le, Q. V., \& Rishi, M. (2012). Foreign direct investment and institutional quality: Some empirical evidence. International Review of Financial Analysis. https://doi.org/10.1016/j.irfa.2011.10.001

Cheng, L. K., \& Kwan, Y. K. (2000). What are the determinants of the location of foreign direct investment? The Chinese experience. Journal of International Economics. https://doi.org/10.1016/S0022-1996(99)00032-X

Donaubauer, J., Meyer, B. E., \& Nunnenkamp, P. (2016). A New Global Index of Infrastructure: Construction, Rankings and Applications. World Economy. https://doi.org/10.1111/twec.12290

Dunning, J. H. (1988). THE ECLECTIC PARADIGM OF INTERNATIONAL PRODUCTION: A RESTATEMENT AND SOME P...: EBSCOhost.

Dunning, J. H., \& McQueen, M. (1981). The eclectic theory of international production: A case study of the international hotel industry. Managerial and Decision Economics. https://doi.org/10.1002/mde.4090020401

Engle, R. F., \& Granger, C. W. J. (2006). Co-Integration and Error Correction: Representation, Estimation, and Testing. Econometrica. https://doi.org/10.2307/1913236

Erenburg, S. J. (1993). The real effects of public investment on private investment. Applied Economics. https://doi.org/10.1080/00036849300000137

Feldstein, M. (2000). Aspects of Global Economic Intergration: Outlook for the Future. https://doi.org/10.3386/w7899

Flores, R. G., \& Aguilera, R. V. (2007). Globalization and location choice: An analysis of US multinational firms in 1980 and 2000. Journal of International Business Studies. https://doi.org/10.1057/palgrave.jibs.8400307

Ghatak, S., \& Siddiki, J. U. (2001). The use of the ARDL approach in estimating virtual exchange rates in India. Journal of Applied Statistics. https://doi.org/10.1080/02664760120047906

Globerman, S., \& Shapiro, D. (2003). Governance infrastructure and US foreign direct investment. Journal of International Business Studies. https://doi.org/10.1057/palgrave.jibs.8400001

Herzer, D. (2010). Outward FDI and economic growth. Journal of Economic Studies. https://doi.org/10.1108/01443581011075424

Holtz-Eakin, D. (2006). Public-Sector Capital and the Productivity Puzzle. The Review of Economics and Statistics. https://doi.org/10.2307/2109822 


\section{INSIGHTS INTO REGIONAL DEVELOPMENT}

ISSN 2669-0195 (online) http://jssidoi.org/jesi/

2021 Volume 3 Number 2 (June)

http://doi.org/10.9770/IRD.2021.3.2(1)

Holtz-Eakin, D., \& Schwartz, A. E. (1995). Spatial productivity spillovers from public infrastructure: Evidence from state highways. International Tax and Public Finance. https://doi.org/10.1007/BF00872777

Iamsiraroj, S., \& Ulubaşoğlu, M. A. (2015). Foreign direct investment and economic growth: A real relationship or wishful thinking? Economic Modelling. https://doi.org/10.1016/j.econmod.2015.08.009

Jiao, J., Wang, J., Jin, F., \& Dunford, M. (2014). Impacts on accessibility of China's present and future HSR network. Journal of Transport Geography. https://doi.org/10.1016/j.jtrangeo.2014.07.004

Johansen, S. (2006). Estimation and Hypothesis Testing of Cointegration Vectors in Gaussian Vector Autoregressive Models. Econometrica. https://doi.org/10.2307/2938278

Kevin Honglin Zhang. (2001). Does Foreign Direct Investment Promote Economic Growth? Evidence from East Asia and Latin America. Contemporary Economic Policy. https://doi.org/10.1111/j.1465-7287.2001.tb00059.x

Khadaroo, J., \& Seetanah, B. (2008). The role of transport infrastructure in international tourism development: A gravity model approach. Tourism Management. https://doi.org/10.1016/j.tourman.2007.09.005

Khan, H., \& Khan, U. (2019). Financial development and FDI inflows in China. Special Issue Recent Developments in International Economics) JEL.

Khan, H., Khan, U., Jiang, L. J., \& Khan, M. A. (2020). Impact of infrastructure on economic growth in South Asia: Evidence from pooled mean group estimation. Electricity Journal, 33(5), 106735. https://doi.org/10.1016/j.tej.2020.106735

Khan, H., Shaheen, I., Ahmad, M., Bakhshaliev, E., Khan, H. U., \& Kabir, A. (2020). Energy infrastructure and foreign direct investment in china. Entrepreneurship and Sustainability Issues, 8(1), 233-248. https://doi.org/10.9770/jesi.2020.8.1(16)

Khanna, T., \& Rivkin, J. W. (2001). Estimating the performance effects of business groups in emerging markets. Strategic Management Journal. https://doi.org/10.1002/1097-0266(200101)22:1<45::AID-SMJ147>3.0.CO;2-F

Laurenceson James; Chai C.H. Joseph. (2003). Financial Reform and Economic Development in China. Edward Elgar Publishing.

Lee, C. G. (2010). Outward foreign direct investment and economic growth: Evidence from Japan. Global Economic Review. https://doi.org/10.1080/1226508X.2010.513143

Limao, N. (2001). Infrastructure, Geographical Disadvantage, Transport Costs, and Trade. The World Bank Economic Review. https://doi.org/10.1093/wber/15.3.451

Loree, D. W., \& Guisinger, S. E. (1995). Policy and Non-Policy Determinants of U.S. Equity Foreign Direct Investment. Journal of International Business Studies. https://doi.org/10.1057/palgrave.jibs.8490174

Loungani, P., \& Razin, A. (2001). How beneficial is foreign direct investment for developing countries? Finance and Development.

Markusen, J. R., \& Venables, A. J. (1999). Foreign direct investment as a catalyst for industrial development. European Economic Review. https://doi.org/10.1016/S0014-2921(98)00048-8

Nadiri, M. I., \& Mamuneas, T. P. (2006). The Effects of Public Infrastructure and R \& D Capital on the Cost Structure and Performance of U.S. Manufacturing Industries. The Review of Economics and Statistics. https://doi.org/10.2307/2109823

North, D. C. (1990). Institutional Change and Economic Performance. In Cambridge University Press. https://doi.org/10.2307/2234910

Odhiambo, N. M. (2009). Energy consumption and economic growth nexus in Tanzania: An ARDL bounds testing approach. Energy Policy. https://doi.org/10.1016/j.enpol.2008.09.077

Ouattara, B. (2006). Aid, debt and fiscal policies in Senegal. Journal of International Development. https://doi.org/10.1002/jid.1282

Ouyang, M., \& Peng, Y. (2015). The treatment-effect estimation: A case study of the 2008 economic stimulus package of China. Journal of Econometrics. https://doi.org/10.1016/j.jeconom.2015.03.017

Pesaran, M. H., Shin, Y., \& Smith, R. J. (2001). Bounds testing approaches to the analysis of level relationships. Journal of Applied Econometrics. https://doi.org/10.1002/jae.616

Phillips, P. C. B., \& Hansen, B. E. (1990). Statistical Inference in Instrumental Variables Regression with I(1) Processes. The Review of Economic Studies. https://doi.org/10.2307/2297545

Shatz, H. J., \& Venables, A. J. (2000). The Geography of International Investment. In The Oxford Handbook of Economic Geography. https://doi.org/10.2139/ssrn.630710

Wheeler, D., \& Mody, A. (1992). International investment location decisions. The case of U.S. firms. Journal of International Economics. https://doi.org/10.1016/0022-1996(92)90050-T

World Bank. (2018). World Development Indicators Data Catalog. In The World Bank. 
INSIGHTS INTO REGIONAL DEVELOPMENT

ISSN 2669-0195 (online) http://jssidoi.org/jesi/

2021 Volume 3 Number 2 (June)

http://doi.org/10.9770/IRD.2021.3.2(1)

Faisal MEHMOOD is the doctoral student of public administration and Assistant Director, Quality Enhanncment Cell, Kohat University of Science \& Technoloy, Kohat. He is interested to hightlight the significance of Special Economic Zones and their associated benefits related to socioeconomic development.

ORCID ID: orcid.org/0000-0002-3948-7819

Muhammad ATIQUE is the doctoral student of public administration in E-government. He is interested to hightlight the significance of E-government and its associated benefits.

ORCID ID: orcid.org/ 0000-0002-7157-8702

Professor Wang BING has doctorate degree in enivornment economics. His areas of interest are environment economics, public administration, foreign investments, and special economic zones.

ORCID ID: orcid.org/0000-0003-2322-5387

Dr. Hameed KHAN is Doctoral in Economics from Jilin University, Changchun, China. Currently, he is working at Kohat University of Science \& Technology, Kohat, Pakistan. His research interests consist of MNCs, Finance, and Institutions.

ORCID ID: 0000-0003-1775-0687

Ms. HENNA did MS from Preston University Kohat campus, Pakistan. Currently, she is working as a visiting lecturer at Government Postgraduate Girls College, Kohat. Pakistan. Her research interests consist of Finance and Accounting.

ORCID ID: 0000-0003-3012-3047

Copyright (C) 2021 by author(s) and VsI Entrepreneurship and Sustainability Center

This work is licensed under the Creative Commons Attribution International License (CC BY).

http://creativecommons.org/licenses/by/4.0/

cC) (i) Open Access 